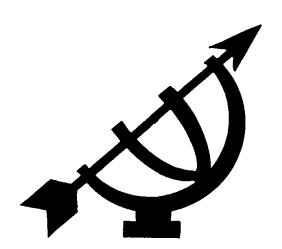

\title{
Die Instituut vir Reformatoriese Studie (1962-1999) as Christelike organisasie - die betekenis daarvan vir toekomstige Christelike aksies
}

\author{
B.J. van der Walt \\ Skool vir Filosofie \\ Potchefstroomkampus \\ Noordwes-Universiteit \\ POTCHEFSTROOM \\ E-pos: hannah@intekom.co.za
}

\begin{abstract}
The Institute for Reformational Studies (1962-1999) as a Christian organisation - its relevance for future Christian actions

During a period of 37 years the Institute for Reformational Studies (IRS) fulfilled a unique role at the former Potchefstroom University for Christian Higher Education. In spite of this, the IRS was closed down at the end of 1999. This happened while, in an increasingly secularised South Africa, there clearly is a growing need to provide direction in all domains of life. This article, therefore, asks the question about possible reasons for the termination of this Institute. The answer to the problem is given from a worldview perspective. The aim of the investigation is to provide, derived from the history of the IRS, some practical guidelines to future Christian actions.
\end{abstract}

\section{Opsomming}

Die Instituut vir Reformatoriese Studie (1962-1999) as Christelike organisasie - die betekenis daarvan vir toekomstige Christelike aksies

Vir 37 jaar het die Instituut vir Reformatoriese Studie (IRS) 'n besondere plek aan die destydse Potchefstroomse Universiteit vir Christelike Hoër Onderwys gehad. Ten spyte daarvan is die IRS einde 1999 gesluit. Dit het gebeur terwyl daar in 'n toenemende gesekulariseerde Suid-Afrika 'n steeds groter 
behoefte bestaan aan Christelike organisasies wat op allerlei terreine lewensbeskoulike leiding kan bied. Hierdie artikel stel dus die vraag na die moontlike redes vir die terminering van die IRS. Dié probleem word uit 'n lewensbeskoulike hoek benader. Die doel van die ondersoek is om uit die geskiedenis van die IRS enkele riglyne vir toekomstige Christelike aksies te bied.

\section{Probleem, hipotese, doel en opset}

Die probleem wat in hierdie artikel ondersoek word, is waarom die Instituut vir Reformatoriese Studie (IRS) na 37 jaar gesluit is. Die hipotese is dat 'n belangrike rede daarvoor die botsing tussen twee verskillende Christelike lewensvisies kon wees. Die oogmerk met die ondersoek is nie om 'n teoreties-prinsipiële regverdiging vir die noodsaaklikheid van Christelike organisasies en instellings te bied nie, maar om uit die geskiedenis van die IRS enkele meer praktiese riglyne vir toekomstige Christelike aksies te bied.

Om die probleem op te los en die doel met hierdie ondersoek te bereik, word die volgende stappe gevolg:

- Ter inleiding word agtereenvolgens kortliks eers aandag gegee aan die belangrikheid van Christelike organisasies volgens die Reformatoriese lewensvisie, daarna aan die metode waarvolgens die geskiedenis van die IRS vanuit 'n lewensbeskoulike hoek benader sal word, en word na die bronne vir die skryf van sy geskiedenis verwys.

- Hierna volg 'n tipering van die IRS - sy doelstelling, aktiwiteite, karakter en plek aan die PU vir $\mathrm{CHO}$.

- Dit word gevolg deur 'n kort oorsig in drie fases van sy geskiedenis vanaf 1962 tot 1999.

- Hierna volg die moontlike redes vir sy sluiting.

- Ten slotte word uit die redes vir die IRS se suksesse sowel as sy sluiting enkele riglyne vir toekomstige Christelike aksies genoem.

\section{Aktualiteit, metode en bronne}

\subsection{Die aktualiteit}

Die sekularisasie in Suid-Afrika van veral die openbare lewensterreine het die afgelope tyd skrikwekkende afmetings aangeneem (vgl. Van der Walt, 2004a; 2004b en 2005a). Dit wil lyk asof Christene, ten spyte van hulle getalle (meer as $70 \%$ van die totale 
Suid-Afrikaanse bevolking) magteloos is om hierdie toenemende verwêreldliking te stuit. Volgens die Reformatoriese lewensvisie bestaan daar wel 'n manier om hierdie tendens op alle lewensterreine te bekamp: deur middel van Christelike organisasies en instellings. Die IRS was so 'n Reformatories-Christelike organisasie. Besinning oor sy geskiedenis (doelstelling, aktiwiteite en karakter) mag dus belangrike praktiese implikasies vir bestaande en toekomstige Christelike aksies inhou. Aangesien daar reeds heelwat teoretiese besinning oor en regverdiging vir Christelike organisasies bestaan (vgl. byvoorbeeld Buijs et al., 2003; Klapwijk, 1995 en Van der Walt, 2003a), word dit nie hier herhaal nie.

\subsection{Die metode}

Twee sake word hier verduidelik: (1) 'n lewensbeskoulike benadering om die geskiedenis te analiseer en te beskryf en (2) persoonlike weergawes van die geskiedenis as aanvaarbare historiografie.

\subsubsection{Lewensbeskoulike historiografie}

Soos enige ander wetenskap kan die geskiedeniswetenskap slegs beperkte insig bied - dit is feilbare mensewerk. Die Reformatoriese denker, Smit (vgl. Klapwijk, 1987:12-42), praat nie sonder rede van "'n goddelike geheim" in die geskiedenis nie. Hy noem dit die "eerste geskiedenis" waarin die voorhande ("tweede") geskiedenis gewortel is.

Geskiedskrywing is ook nie iets objektief-neutraal nie. Tereg sê Wells (1989:8): "The facts of history simply do not speak for themselves: historians speak for them from an interpretive framework of ideas they already hold." Hierdie denkraamwerk is die lewensvisie van geskiedkundiges.

Dit is tipies van 'n lewensvisie dat dit selde eksplisiet gestel word. Die voorstander van ' $n$ bepaalde lewensvisie is meestal nie bewus daarvan nie en kan daarom maklik ook die "gevangene" daarvan word.

Wells gebruik die konsep van lewensvisie metodologies op twee maniere in sy historiografie van die Westerse kultuurgeskiedenis. Hy analiseer die verloop van die Westerse geskiedenis eerstens na aanleiding van botsende lewensvisies en in die tweede plek na aanleiding van krisisse binne dieselfde lewensvisie (vgl. Wells, 1989:13). 
Enige lewensvisie bevat 'n deskriptiewe element (die werklikheid is só) sowel as 'n preskriptiewe faset (dit behoort só verander te word). 'n Mate van spanning tussen die is en die behoort is normaal. Indien dié spanning egter te groot word, klop 'n mens se visie van die werklikheid nie meer met jou visie vir die werklikheid nie, en beland jou lewensbeskouing in 'n krisis. In so 'n geval moet 'n mens se visie op die werklikheid óf aangepas (verander) word, óf verwerp (vervang) word.

Dieselfde lewensbeskoulike metode sal ook in hierdie ondersoek gebruik word. Die hipotese is dat altwee bogenoemde prosesse ook in die geskiedenis van die IRS plaasgevind het.

In die eerste plek het die meer integrale Reformatoriese lewensvisie, wat deur die IRS voorgestaan is, geleidelik begin bots met die meer dualistiese Christelik-nasionale lewensvisie aan die $\mathrm{PU}$ vir $\mathrm{CHO}$ (of kortweg, die PUK). Die twee lewensvisies het verskillende sienings gehuldig oor hoe die Suid-Afrikaanse (veral politiek-sosiale) werklikheid is en ook hoe dit behoort te wees. (Vir leiers aan die PUK het die is en die behoort nader aan mekaar gelê as vir die IRS.)

In die tweede plek het die PUK-leiers se Christelik-nasionale lewensvisie, wat die apartheidsideologie geakkommodeer het, geleidelik, maar veral vanaf ongeveer 1990 problematies geword. Hulle lewensvisie en die werklikheid rondom hulle het, as gevolg van veranderinge op politiek-sosiale gebied, nie meer gekorrespondeer nie en 'n eksistensiële krisis het ontstaan. Aanvanklik het 'n mens die indruk gekry dat hulle (in plaas daarvan om te reformeer, hulle lewensvisie te vernuwe) hulself dieper in hul lewensbeskoulike "loopgrawe" teruggetrek het. Dit wil voorkom asof die uiteindelike gevolg was dat die Christelik-nasionale lewensvisie geleidelik sy invloed verloor het. Net so geleidelik en ongemerk is die lewensbeskoulike vakuum - mede as gevolg van politieke druk van die nuwe politieke bedeling sedert 1994 - met 'n meer sekulêre lewensvisie gevul.

Hierdie persoonlike uitgangspunt (vgl. ook later onder 5.1 tot 5.5) word bloot as ' $n$ voorlopige hipotese voorgehou. Dit bevat dus die uitnodiging om deur ('n) toekomstige navorser(s) getoets te word. So iets sou gedoen kon word deur verdere navorsing in die universiteitsannale (bv. notules van die Raad van die $\mathrm{PU}$ vir $\mathrm{CHO}$ ) asook persoonlike onderhoude met destydse universiteitsleiers. ' $n$ Veel breër - en dalk totaal ander - blik op die geskiedenis mag dan ontvou. Die bedoeling van die hipotese wat hier gebruik word (die 
botsing tussen twee Christelike lewensvisies) wil die ondersoek op 'n meer onpersoonlike, objektiewe vlak plaas. Hierdie benadering voorkom dat dít wat volg geïnterpreteer mag word as persoonlike aantygings of refleksies op die integriteit van diegene wat destyds besluite oor die IRS moes neem.

\subsubsection{Betrokke historiografie}

Sonder die nodige versigtigheid, kan geskiedskrywing deur iemand wat self nóú by 'n geskiedenis betrokke was, nadele inhou (vgl. Overduin, 1978:242-252, asook Klep, Hoetink \& Emons, 2005:5783). Eerstehandse, persoonlike weergawes ('n sogenaamde deelnemer-perspektief) kan egter ook voordele inhou. Dit val egter buite die bestek van hierdie artikel om op al die probleme en moontlikhede van die meer subjektiewe, postmoderne benadering tot geskiedskrywing, in te gaan. Daar word met enkele opmerkings volstaan.

Klep, Hoetink en Emons (2005:79) waarsku teen die volgende twee eensydighede: Aan die een kant is die mening dat 'n mens ' $n$ betrokkene of ten minste 'n tydgenoot moet wees om werklik te kan weet wat gebeur het en dit te kan beoordeel. Aan die ander kant is die standpunt dat 'n mens slegs as 'n onbetrokke buitestander, vanaf 'n sekere distansie, die geskiedenis korrek kan weergee. Soos ook Wells (1989) hierbo aangetoon het, bly sowel betrokke as onbetrokke historiografie egter selektief.

Tot ongeveer 'n dekade gelede (toe die modernistiese wetenskapsideaal nog hoogty gevier het) was akademiese geskiedskrywing deur 'n onafhanklike buitestander feitlik die enigste aanvaarbare wyse om die "waarheid" in die geskiedenis vas te stel, aangesien dit objektief en neutraal sou wees. Klep, Hoetink \& Emons, (bevestig deur ander resente werke) toon egter aan dat dit as gevolg van die invloed van die postmodernisme nie meer die heersende paradigma is nie. Meer persoonlike weergawes word as ewe waardevol erken en is selfs meer populêr as akademiese geskiedenisboeke.

Die nuutste tendens is dus dat die twee vorme van historiografie mekaar nie behoort te bestry nie, maar eerder wedersyds moet aanvul. Dit blyk byvoorbeeld duidelik uit die Reformatoriese filosoof, Klapwijk, se bydrae in hierdie gedenkuitgawe van Koers. Hy onderskei tussen twee soorte geskiedenis. Die "eerste geskiedenis" is soos wat ons die geskiedenis persoonlik "van binne-uit" beleef en herdenk. Die "tweede geskiedenis" is die geskiedenis soos wat die Geskiedeniswetenskap die gebeure uit die verlede op grond van 
histories-kritiese ondersoek van die feite (re)konstrueer. (Kortweg sou eersgenoemde 'n deurleefde en laasgenoemde 'n gekonstrueerde geskiedenis genoem kon word.) Volgens Klapwijk is albei nodig.

In die geval van hierdie ondersoek word hierdie gebalanseerde standpunt aanvaar. Die outeur van hierdie artikel is bewus van die leemtes van sy eie weergawe van die geskiedenis van die IRS (vgl. Van der Walt, 2000:149), maar is oortuig van die waarde wat dit kan hê. Sy wens is dat sy eie "betrokke historiografie" in die toekoms nog gekomplementeer en selfs gekorrigeer sal word deur die "onbetrokke historiografie" van 'n onafhanklike geskiedkundige.

\subsection{Die bronne}

Enkele flitse en fragmente oor die geskiedenis van die IRS bestaan reeds (vgl. Van der Merwe, 2000; Van der Walt, 1983a; 1989a en 2000; en Van Eeden, 2005:168-170). 'n Geheeloorsig ontbreek egter.

'n Nog ongepubliseerde weergawe deur Van der Walt, 2005b, is ter insae by die argief van die Potchefstroomkampus van die Noordwes-Universiteit. Hierdie werk is gegrond op die jaarverslae van die Instituut vir die Bevordering van die Calvinisme (IBC) vanaf 1974 tot 1980 en die jaarverslae van die Instituut vir Reformatoriese Studie (IRS) vanaf 1981 tot 1999, almal in besit van genoemde argief. (Hierdie werk is gedoen omdat die jaarverslae 'n betroubare weerspieëling bied van die werksaamhede en probleme van die IBC en latere IRS oor 'n bepaalde jaar. Dit is amptelik deur die Raad van die IBC/IRS as betroubare weergawes aanvaar.) Hierdie artikel is 'n meer feitelike samevatting van genoemde manuskrip (46 bladsye), wat die meer kleurryke geskiedenis van die IRS skilder.

Die talle notules van die IBC/IRS se Dagbestuur en Raad (en ná 1991 dié van die Senaatskomitee vir Reformatoriese Wetenskap) bevat nog meer detail vir moontlike verdere navorsing. Dieselfde geld van die IRS se konferensieverslae en -besluite waarvan die meeste in die Circular en later in Orientation gepubliseer is. Daar is ook nog die Fakulteits- en Raadsnotules wat die breëre Universiteitskonteks waarbinne die IRS bestaan het, kan ophelder. 


\section{3. 'n Tipering van die IRS as 'n Christelike organisasie en sy plek aan die PU vir $\mathrm{CHO}$}

Vir die verstaan van die verloop van die geskiedenis van die IRS, is die volgende belangrik: sy doelstelling, aktiwiteite, karakter, plek en veranderende rol aan die Universiteit.

\subsection{Doelstelling}

Die doelstelling het soos volg gelui: "Die IRS stel hom ten doel om in die koninkryk van God diensbaar te wees deur die bestudering en uitdra van die Reformatoriese tradisie, veral soos dit in die Calvinistiese lewensbeskouing tot vergestalting gekom het" (Van der Walt, 1983a: 6, 17).

Die doel van die IBC/IRS het dwarsdeur sy bestaan dus twee fokuspunte gehad: sowel 'n teoretiese of akademiese fokus, naamlik navorsing oor die Reformatoriese lewensvisie, asook die popularisering en praktiese toepassing van dié lewensvisie op alle lewensterreine (vgl. ook Duvenage, 1983:17 en Van der Walt, T., 1983:27).

Soos nog later sal blyk, het veral die tweede fokuspunt van die IRS gedurende sy herfsjare vir die Universiteitsoutoriteite 'n probleem geskep, toe geblyk het dat die toepassing van 'n Bybelse lewensvisie nie die apartheidsideologie kon regverdig nie.

\subsection{Aktiwiteite}

In ooreenstemming met sy doelstelling het die IRS deur die jare soms met groter aksent op die een as die ander - die volgende aktiwiteite onderneem:

- Navorsing is gedoen oor veral die Reformatoriese tradisie en die implikasies daarvan.

- Vyf verskillende reekse publikasies (F1 tot F5 in die reeks Wetenskaplike Bydraes van die $P U$ vir $\mathrm{CHO}$ ) is uitgegee, waarvan sommige (bv. F1-Studiestukreeks) meer populêr en ander (bv. F4 en F5) meer akademies van aard was, asook (vanaf 1975-1999) 'n internasionale tydskrif, die Circular (namens die internasionale aksie vir $\mathrm{CHO}$ ) wat later herdoop is tot Orientation, international circular of the PU for CHE.

In die jaarverslag van 1999 word meegedeel dat by die IRS gedurende die 37 jaar van sy bestaan nie minder nie as 384 
studiestukke, 76 brosjures en 51 versamelwerke die lig gesien het. Dit is buiten die nommers wat in die reeks F4 (Calvyncauserieë) en die reeks F5 (Studies oor die inslag van die Calvinisme in Suid-Afrika) gepubliseer is en die 90 nommers van Orientation, asook die talle kere wat publikasies herdruk is.

- Ongeveer 20 konferensies van plaaslike en internasionale omvang oor uiteenlopende aktuele onderwerpe is aangebied.

- Die uitbou en onderhouding van kontak met geesgenootlike instellings en persone, versameling en die deurgee van inligting (bv. die Klaringshuis wat veral internasionaal op Christelike Hoër Onderwys toegespits het) is onderneem.

Ook dié aktiwiteite van die IRS het sowel op die Christelikakademiese as Christelik-lewensbeskoulike (meer praktiese) vlak plaasgevind. Die IRS was dus nie 'n "ivoortoring"-instituut nie, maar het teorie en praktyk gekombineer om werklik diensbaar te kon wees in die omvattende koninkryk van God (vgl. doelstelling hierbo).

\section{3 'n Besinnnend-rigtinggewende Christelike organisasie}

Volgens Klapwijk (1995:119-120) se indeling van Christelike organisasies en instellings in vier kategorieë, word die IRS deur die derde groep gekarakteriseer. Klapwijk beskryf dit soos volg:

Christelijke verbanden die in de samenlewing in eerste instantie invloed willen uitoefenen en dat vanuit een christelijke overtuiging, soals christelijke partijen, vakorganisaties, pers- en omroeporganisaties en allerlei (middelbare en hogere) onderwijsinstellingen [...]. Het gaat hier om verbanden die stuur en richting hebben te geven aan de samenleving door wetenschappelijke bezinning (universiteiten en hogescholen), door politieke strijd (partijen), door sociale actie (vakbeweging) en door opinievorming (omroep- en persorganisaties). In deze verbanden is het voortdurend nodig strijd te leveren, positie te kiezen, prioriteiten te stellen. En zoiets geschied in mindere of meerdere mate vanuit een levensbeschouwlijke overtuiging.

Die IRS pas by hierdie omskrywing van 'n Christelike organisasie of instelling. Tog het dit 'n unieke posisie gehad, omdat dit aan die PUK verbonde was.

\subsection{Die karakter van die IRS nader getipeer}

Met die volgende trefwoorde tipeer Van der Walt (1983a:8) die IRS - ten minste tot 1991 (toe dit in die Senaatskomitee vir 
Reformatoriese Wetenskap "opgeneem" is): 'n instituut (nie bv. 'n vereniging nie); 'n universitêre instituut (dus duidelik akademies van aard); 'n interfakultêre instituut (dus nie aan net een departement of fakulteit verbonde nie); 'n kerninstituut, omdat dit dié organisasie is waardeur die Universiteit sy beginselstandpunt op lewensbeskoulike vlak landswyd en ook internasionaal bemark; 'n interkerklike instituut, omdat die IRS met ander Christelike organisasies oor kerkgrense heen saamwerk en hulle ook op die IRS se Raad van Beheer verteenwoordig is.

Soos sal blyk, was dit heelwaarskynlik die IRS se karaktertrek van kerninstituut wat in sy herfstyd vir die Universiteitsowerhede problematies was, omdat die IRS die aanvaarding van apartheid aan die PUK bevraagteken het.

\subsection{Posisie aan die Universiteit}

Omdat die IRS 'n interfakultêre instituut was en daar ook buiteuniversitêre instansies op sy Raad gedien het, het dit heelwaarskynlik meer beweegruimte as 'n blote departementele instituut gehad. Tog was dit 'n deel van die PUK. Hoewel dit uit ledegelde en boekverkope heelwat self verdien het, was die IRS vir sy bestaan van die Universiteit afhanklik. Die Universiteitsbestuur, wat op die Dagbestuur en Raad van die IRS gedien het (die Rektor was byvoorbeeld ex officio voorsitter van die IRS-Raad en Dagbestuur), het ook 'n groot invloed gehad. (Prof. H.J.J. Bingle het as voorsitter van die IRS gedien tot 1977, prof. T. van der Walt tot 1987 en prof. C.J. Reinecke tot 1999.) Toe die IRS (vanaf 1991) sy eie Raad en Dagbestuur verloor het (by die SRW ingeskakel is), het dit die relatiewe selfstandigheid wat dit tot dusver geniet het, verloor.

\section{6 'n Verskuiwing vanaf venster van die PUK na venster op die PUK}

Soos reeds aangetoon, was 'n uitgesproke doelstelling van die IRS onder andere om 'n (vertoon)venster na buite te wees van die PUK se Christelike ideale. Die IRS het daarin geslaag om die Universiteit (veral wat Christelike Hoër Onderwys betref) op die wêreldkaart te plaas. Daarbenewens het dit ook steeds probeer om op verskillende maniere die PUK (studente en dosente) te dien. Baie gedagtes wat in die IRS self ontstaan het en later deur die Universiteit verder ontwikkel is, het daartoe bygedra dat die PUK se beeld na buite nog verder versterk is. Enkele voorbeelde hiervan is die Komitee vir Buitelandse Betrekkinge; die beklemtoning van die noodsaaklikheid van vertaling in Engels; die ontsluiting van die vroeg-Reformatoriese 
tradisie; die Calvyn-navorsing en -vertaalsentrum. (Vir die agtergrond van laasgenoemde projek, vgl. Van der Walt, 1980b.)

\subsubsection{Venster op die PUK self}

Met die sterker uitwaartse beweging van die IRS vanaf ongeveer 1983 (vgl. byvoorbeeld Van der Walt, 1983b) het steeds meer "vensters" op die wêreld vir die IRS oopgegaan. Van der Walt (2000:151-155) noem die volgende: venster op die Suid-Afrikaanse Calvinisme; venster op die hele Reformatoriese tradisie; venster op Christelike Hoër Onderwys; venster op Afrika; venster op die wêreld (vir detail hieroor vgl. Van der Walt, 2005c); en venster op SuidAfrika en die PUK self.

Geleidelik het die eenrigtingverkeer (vanaf die PUK na buite) in 'n tweerigtingverkeer (ook van buite af na die PUK) verander. Die verkenning van 'n groot, onbekende wêreld "anderkant die Mooirivier" het daartoe gelei dat die IRS ook na binne, na homself en na sy "moeder" (die PUK) begin kyk het - in plaas daarvan om net 'n venster van die PUK te wees, het die IRS ook 'n venster op die PUK geword.

Die IRS-direkteur gebruik die beeld van tweerigtingverkeer oor 'n brug (die IRS) en skryf: "Gekontroleerde tweerigtingverkeer oor hierdie brug is myns insiens die regte strategie." Dit stel hy teenoor sowel isolasie as akkommodasie:

Die IRS kan onmoontlik sy werk doen sonder om kennis te neem van wat op die Suid-Afrikaanse en wêreldmark aan geestelike goedere (gedagtes, beskouings en ideologieë) te koop aangebied word. Terselfdertyd moet dit met 'n heilige geroepenheid missionêr as brug dien om die bevrydende perspektiewe van 'n reformatories-evangeliese lewensvisie die wêreld in te dra (Van der Walt, 1989a:5).

Dat dié pad nie vir die IRS maklik sou wees nie, blyk uit die volgende woorde:

Juis omdat die IRS so 'n belangrike brugfunksie vervul, is dit dikwels omstrede en sal dit (met die toenemende polarisasie in ons land) in die toekoms heelwaarskynlik nog meer omstrede moet word in sy roepingsvervulling. Omstredenheid as sodanig is egter nog nie 'n bewys dat iemand of ' $n$ instelling verkeerd is nie. Volgens Christus kan dit juis 'n bewys wees dat die gelowiges op die regte pad is (vgl. Matt. 5:10,11) (Van der Walt, 1989a:5). 


\subsubsection{Die gewete van die PUK}

Omdat die IRS al meer ook 'n venster op die PUK - die gewete van sy moeder - geword het, moes dit haar ook ernstig aanspreek. 'n Duidelike voorbeeld van dié gewetensrol wat die IRS in sy laatsomer en herfstyd moes speel, is die jarelange stryd wat dit gevoer het dat die universiteit ook sy deure sou oopmaak vir "anderskleuriges" op voorgraadse vlak en - uiteindelik - ook sy koshuise vir hierdie studente sou oopstel. (Vgl. Venter, 1984 en ook Van der Walt, 1989b:54-67 vir 'n volledige oorsig van die IRS se bydrae in dié verband.)

Die skrywer se hipotese is dat hierdie gewetenstem van Potchefstroom - die venster op die PUK - dit vir die gesagsfigure aan die Universiteit ongemaklik gemaak het, omdat dit met hulle eie lewensvisie gebots het.

\section{Die geskiedenis van die IRS in hooftrekke}

Nadat die besondere posisie van die IRS aan die PUK verduidelik is, word kortliks nagegaan hoe die IRS sy taak en rol vervul het.

\subsection{Drie hoofperiodes}

Op grond van wat met die IRS gedurende 37 jaar gebeur het, kan sy geskiedenis in die volgende drie fases ingedeel word:

- 'n Lentetyd, wat strek vanaf 1962 tot ongeveer 1974 (12 jaar). Dit is die tyd van lentebloeisels, vol van beloftes vir die toekoms.

- 'n Somertyd, wat die periode van ongeveer 15 jaar vanaf 1975 tot ongeveer 1990 dek. Moontlik sou dit nog verder in twee subfases verdeel kon word, naamlik vanaf 1975 tot ongeveer 1983 was die IRS nog sterk na binne gerig, terwyl dit vanaf 1983 (vgl. byvoorbeeld die Eerste Suider-Afrikaanse Konferensie waaroor Van der Walt, 1983b rapporteer) al sterker na buite beweeg. Hierdie "somertyd" was die tyd om die vrugte (wat die lentebloeisels belowe het) te oes.

- 'n Herfstyd, wat strek vanaf ongeveer 1991 (die opname van die IRS in die SRW) tot met die sluiting van die IRS in 1999 (die winter). Soos 'n mens gedurende die herfs nog laatvrugte kan oes, beteken dit nie dat daar niks meer by die IRS gebeur het nie. Hierdie periode word egter die herfstyd genoem, omdat die IRS gedwing is om te "rasionaliseer" en ook op ander maniere onder druk gekom het. 
Van der Walt (2005b) behandel elkeen van hierdie "seisoene" in besonderhede. In hierdie artikel word slegs gekonsentreer op die geleidelike verskuwing in die denkklimaat (lewensvisie) wat ook die IRS uiteindelik nadelig sou tref.

\subsection{Lentetyd (1962-1974)}

Gedurende hierdie tyd was daar nie noemenswaardige verskille tussen die lewensbeskoulike ingesteldheid van die PUK en die IBC nie. Hoewel enkele persone, soos prof. J.H. Coetzee ('n lid van die IRS-Raad) die apartheidsbeleid begin bevraagteken, geskied dit nog vanuit die min of meer algemeen aanvaarde Christelik-nasionale lewensvisie - die vorm waarin die Calvinisme in Suid-Afrika gestalte geneem het (vgl. Coetzee, 1987). In Van der Walt (1980a) kan onder die trefwoorde "Christelik-nasionaal" en veral "Christeliknasionale onderwys" talle verdedigings van dié lewensvisie uit hierdie tyd opgespoor word. Soos reeds gesê, bepaal 'n lewensvisie tot 'n groot mate die geestesklimaat van 'n tyd, sodat baie meer mense dit ondersteun het as net dié wat hulle eksplisiet daaroor uitgelaat het.

Terselfdertyd is daar reeds gedurende die lentetyd van die IRS aanduidings van veranderende tye. Voorbeelde daarvan (vgl. Van der Walt, 2005b:17) is onder andere die volgende drie IBCpublikasies: Reformasie of revolusie? ('n versamelwerk), J.D. van der Vyver se Menseregte en L.M. du Plessis se Calvyn oor die staat en die reg.

\subsection{Somertyd (1975-1990)}

Vanaf 1975 begin dit geleidelik duidelik word dat die bestaande politieke situasie nie permanent sou kon voortduur nie. Die IBC/IRS begin meer openlik kontroversiële sake behandel in publikasies soos onder andere Geregtigheid in die Suid-Afrikaanse samelewing (1977), Ideologiese stryd in Suid-Afrika (1985) en Calvinism does not teach apartheid (Buys, 1987).

Reeds in 1975 gee die Eerste Internasionale Konferensie vir Christelike Hoër Onderwys daartoe aanleiding dat die PUK se steun vir die apartheidsideologie hom die kritiek van die internasionale gemeenskap op die hals haal. (Vir meer oor dié geskiedenis, vgl. Van der Walt, 2005c.)

As gevolg van die skaakmat (van ongeveer 'n dekade) tussen die PUK en die res van die internasionale Christelike gemeenskap onder leiding van die Vrije Universiteit van Amsterdam, spits die IRS 
vanaf ongeveer 1983 sy aandag meer toe op Afrika (vgl. Van der Walt, 1989b). Ook as gevolg van hierdie breër blootstelling buite Suid-Afrika kon die Suid-Afrikaanse politiek-sosiale situasie nie vermy word nie (vgl. Turaki, 1992). Die IRS word dus al meer 'n kritiese venster op die PUK as bloot 'n uitstalvenster van die Christelike lewensbeskouing van die PUK.

Die besluite van die verskeie Afrika-konferensies van die IRS lei byvoorbeeld tot herhaaldelike kritiek op die Universiteit, omdat dit nie (ook op voorgraadse vlak) Christene uit alle bevolkingsgroepe toelaat om aan die PUK - die enigste uitgesproke Christelike universiteit in die land - te studeer en van sy koshuisgeriewe gebruik te maak nie.

Vanselfsprekend moes dit spanning tussen die moeder (die PUK) en die dogter (die IRS) veroorsaak. Dit was heelwaarskynlik ook 'n rede vir die inperking van die selfstandigheid van die IRS vanaf 1987 (vgl. Jaarverslag 1987). Die IRS-reglement word so gewysig dat dit direk onder die Vise-Rektor (Akademies) sou ressorteer.

Vanaf 1989 word die IRS nog verder gekniehalter toe daar besluit is dat dit vanaf 1990 sy eie Raad, Dagbestuur, Algemene Ledevergadering en Publikasie-komitee (met ander woorde sy relatiewe selfstandigheid) verloor. Die IRS word by die Senaatskomitee vir Reformatoriese Wetenskap (SRW) ingeskakel, word finansieel en wat personeel betref gerasionaliseer, moet sy aktiwiteite afskaal en die direkteur word (voltyds) na die Departement Filosofie oorgeplaas. (Hy het egter verkies om terselfdertyd as direkteur by die IRS aan te bly.)

Reeds aan die einde van die IRS-Jaarverslag van 1988 blyk die uiteengaan van visies en weë duidelik: "Die IRS kies nie tussen links en regs in die Suid-Afrikaanse politieke spektrum nie ... Die IRS wil in die lig van die Skrif 'n derde weg bewandel, wat ons van die eng perspektief van óf links óf regs bevry. Ons Here Jesus Christus het vir ons hierin 'n voorbeeld gestel deur nie vir of teen 'n bepaalde party van sy tyd te kies nie, maar bo hulle almal uit te gaan ...".

Hierna word gesê dat so 'n "derde weg" nie met rose besaai sal wees nie, maar heel moontlik 'n lydensweg sal wees, want so 'n roete maak die IRS kwesbaar, en laat dit in die kruisvuur tussen links en regs beland. Dat dit 'n moeilike weg kan wees beteken egter nie noodwendig dat dit die verkeerde pad is nie (vgl. Matt. 5:10-11). 
Uit die laaste IRS-Jaarverslag (1999:1) blyk egter dat die IRS enduit probeer het om op hierdie derde weg - die Reformatoriese, krities teenoor sowel links as regs - vol te hou.

\subsection{Herfstyd (1991-1999)}

Gedurende die laaste nege jaar (sy herfstyd) kon die IRS gelukkig nog voortgaan (vgl. die betrokke Jaarverslae en Van der Walt, 2005b:27-30 vir besonderhede oor sy aktiwiteite). In sy publikasies (vgl. Van der Walt, 1995a) toon die IRS duidelik aan waarom die Christelik-nasionale lewensvisie nie 'n werklik radikaal-Bybelse lewensperspektief bied nie, maar inherent skisofrenies is en gevolglik dus 'n onregverdige samelewingsbestel kon akkommodeer.

Aangesien dit gedurende hierdie periode duidelik geword het dat die IRS se dae getel kan wees, word daar op verskillende vlakke (van binne die PUK maar ook nasionaal en internasionaal) pleidooie aan die Universiteitsowerhede gerig dat die IRS, in die lig van sy waarde as Reformatoriese organisasie, ondersteun moet word en behoue moet bly. Hierdie versoeke word gerig aan die bestuur tot op die hoogste vlak van die PU-Raad (vgl. Van der Walt, 2005b:28-30).

Op 16/09/1999 besluit die Raad van die Universiteit egter dat die IRS in die (nuwe) Sentrum vir Geloof en Wetenskap (SGW) opgeneem sal word. In 'n laaste omsendbrief (met op die voorblad: IBC-IRS-SGW) wat in die loop van 2000 deur die SGW (in opdrag van die bestuur) aan IRS-lede uitgestuur is, word (op p. 3) as ideaal gestel die "saambundeling van die opdragte van die IRS, Wetenskapsleer en die Sentrum vir Geloof en Wetenskap, gekoördineer met die onderrig en navorsing van die $\mathrm{PU}$ vir $\mathrm{CHO}$. Van die vorige funksies van die IRS sal bly voortbestaan ....".

In die praktyk het dit egter daarop neergekom dat die IRS in die SGW opgeneem is en daarin ondergegaan het - geeneen van die aktiwiteite van die IRS is eventueel voortgesit nie.

Daar is ook nooit - ten minste nie openlik aan die IRS-personeel, -ondersteuners en -lede - gerapporteer presies waarom die IRS gesluit is nie. In genoemde laaste omsendbrief (p. 3) word slegs die volgende gestel: "Indringende besinning het gelei tot die besluit van die Raad van die PU vir $\mathrm{CHO}$ dat die Universiteit strategies al sterker moet fokus op die kerntake van onderrig en navorsing, ook rondom die vraagstukke van geloof en wetenskap." Hiervolgens wil dit lyk asof die IRS sy funksie(s) dermate verloor het dat die 
struktuur ook gesluit moes word. Dit roep vrae op soos presies wanneer, hoe en hoekom dit gebeur het.

Uit die IRS-jaarverslae blyk egter duidelik dat die IRS navorsing gedoen het en dat sy publikasies in verskillende onderrigsituasies nasionaal en internasionaal - wel gebruik is. Bowendien het die IRS in talle publikasies en konferensies die vraagstukke rondom geloof en wetenskap behandel.

Die outeur ontken nie dat die genoemde rede ' $n$ rol kon speel nie. Hy twyfel egter of dit die deurslaggewende rede was en is van mening dat diepere, lewensbeskoulike verskille tussen "moeder" en "dogter" die werklike dryfveer was.

\section{Moontlike redes vir die sluiting van die IRS}

Die lewensbeskoulike posisie van die Universiteitsbestuur word hier hipoteties-vragenderwys benader. (Vir meer detail, vgl. Van der Walt, 2005b:32-38.) Daarmee word vanselfsprekend nóg die persoonlike integriteit van Universiteitsbestuurslede bevraagteken, nóg gesuggereer dat die IRS self destyds alle wysheid in pag gehad het.

\subsection{Onbekendheid met 'n integrale Reformatoriese lewensvisie?}

Die vraag is of die Universiteitsbestuur wel ten volle besef het wat 'n Reformatoriese lewensvisie werklik inhou. Hierdie vraag word gestel ten spyte van die gebruik van die spesifieke begrip en talle publikasies daaroor - ook deur die IRS (vgl. Spykman, 1985; Van der Walt, 1995b; Veenhof, 1994 en Wolters, 1992).

\subsection{Onvermoë/onwilligheid om die implikasies van 'n Christelike lewensvisie na die sosiaal-ekonomiese praktyk deur te trek?}

Selfs al sou die Bestuur op die tweesporige Christelik-nasionale pad geloop het, bly sekere reaksies van die Universiteit moeilik met 'n Christelike oriëntasie versoenbaar. Voorbeelde daarvan uit die geskiedenis is die ontvangs van die Koinonia-verklaring van 1977 (vgl. Van der Walt \& Venter, 1998:31-44); die onwilligheid (1994) om openlik skuld ten opsigte van apartheid te bely (vgl. Van der Walt, 1997 en 1998) en die afsydigheid (in 1996 en daarna) teenoor die Waarheids- en Versoeningskommissie (vgl. Van der Walt \& Van der Walt, 1996). 


\section{3 'n Ontspoorde lewensvisie?}

Heel waarskynlik moet die diepste oorsaak gesoek word in die feit dat die Christelik-nasionale lewensvisie 'n ontspoorde vorm van 'n werklike Bybels-begronde lewensvisie was. Van der Walt (1995a:342) toon aan hoe hierdie lewensvisie van 'n inherente dualisme uitgaan; hoe die klem geleidelik van Christelik-nasionaal na Nasionaal-christelik verskuif het, sodat Afrikaner-nasionalisme die belangrikste komponent daarvan geword het en die apartheidsideologie kon goedkeur. Goudzwaard (1981:40-48 en 1984:39-48) spel die groot gevare uit wat so 'n volksideologie inhou. (Vgl. ook Van der Walt et al., 1984 en Van der Walt, 1989c se waarskuwings in dié verband.)

\section{4 'n Botsing tussen twee lewensvisies?}

Soos onder 2.2.1 hierbo uiteengesit, bevat 'n lewensvisie 'n beskrywende en 'n voorskrywende element (hoe die werklikheid is en hoe dit behoort te wees). Bogenoemde vraag impliseer dus dat die Universiteit die Suid-Afrikaanse en ook die breëre Afrikawerklikheid (die bestaande of feitelike) en hoe dit verander moet word (die normatiewe) anders as die IRS beskou het. Die keuse van die Bestuur was heelwaarskynlik tussen regs of links, status quo of verandering, terwyl die IRS dié dilemma wou vermy deur na 'n derde weg te soek. Toe die twee perspektiewe begin bots het, was dit byna vanselfsprekend dat die visie van die verteenwoordigers van die Universiteitsbestuur sou seëvier, omdat hulle oor die administratief-finansiële mag beskik het om die IRS in te perk en eventueel te sluit.

\subsection{Disintegrasie van die Christelik-nasionale lewensvisie?}

Soos reeds deur Wells (1989) hierbo (vgl. 2.2.1) aangetoon, tree daar 'n krisis in by 'n lewensvisie wanneer die spanning tussen die feitlike werklikheid en die normatiewe eise van die lewensbeskouing te groot word. Dié krisis was reeds voor 1994 sigbaar, maar verdiep gedurende die laaste jare van die IRS se bestaan. Die meeste Afrikaners - ook dié aan die PUK - het hulle politieke mag (die nasionale pool van Christelik-nasionaal) verloor. Omdat die Christelike pool so nóú daaraan gekoppel was, moes dit uiteindelik ook prysgegee word. (Dat dit kon gebeur, is reeds in die sewentigerjare deur die skrywer genoem - vgl. Van der Walt, 1976.) Die verdere verloop by die PUK bevestig dit: Vanaf 2004 moet die Universiteit sy "van" prysgee. Die jongste Vise-Kanselier van die 
Noordwes-Universiteit moes erken dat dit polities nie moontlik was om die "vir CHO" te behou nie (vgl. Van Eeden, 2005:537).

Die vraag kan natuurlik gestel word of die PUK wel sy Christelike karakter sou behou het as dit betyds (bv. reeds in die sestigerjare) sy Christelik-nasionale lewensvisie laat vaar het. Sou dit teen die owerheidsbeleid ingaan, kon dit die opskorting van regeringsteun en dalk die sluiting van die Universiteit tot gevolg gehad het? Om hierdie vraag te beantwoord sal die destydse verhouding tussen 'n (Christelike) universiteit en die Suid-Afrikaanse politieke bestel ondersoek moet word.

\subsection{Sekularisasie in die plek van Christelik-nasionaal?}

Omdat daar na die verlies van die Christelik-nasionale visie nie vernuwing plaasgevind het nie (dus 'n meer integrale Christelike visie die plek daarvan ingeneem het nie), wil dit lyk asof die vakuum geleidelik en ongemerk deur die toenemende sekulêre lewensvisie van die nuwe Suid-Afrikaanse bestel gevul is (vgl. Van der Walt, 2005b:36-37 vir voorbeelde). 'n Mens sou dus kon beweer dat wat met die PUK vanaf 2004 gebeur het, nie net eensydig aan (bv. politieke) faktore buite die Universiteit toegeskryf mag word nie - die PUK het tot 'n groot mate self voorberei wat uiteindelik met hom gebeur het. Die IRS moes alleen vroeër die prys betaal wat die Universiteit vyf jaar later moes doen. Anders gestel: Die IRS het nog minder bestaansreg gehad in 'n sekulêre geestesklimaat as in die (toe reeds uitgediende) Christelik-nasionale.

\section{Enkele riglyne vir toekomstige Christelike aksies}

Die gevolgtrekking van hierdie studie is egter nie dat 'n sekularistiese geestesklimaat Christelike organisasies en instellings onnodig of onmoontlik maak nie. Inteendeel, as gevolg van die groeiende sekularisasie van die Suid-Afrikaanse samelewing, is Christelike organisasies vandag nog meer nodig as in die tyd van die IRS (vgl. Van der Walt, 2003a). Uit sowel die sukses as die ondergang van die IRS word ten slotte enkele wenke vir bestaande en toekomstige Christelike aksies gegee.

\subsection{Enkele "sleutels" tot die werk van die IRS}

Die volgende spreek byna vanself, maar is tog belangrik:

- Die infrastruktuur wat die PU vir $\mathrm{CHO}$ - selfs gedurende die herfsjare - voorsien het. 
- Die groot bydrae van lojale IRS-personeel, IRS-Raads- en -dagbestuurslede,die IRS-publikasiekomitee en verskeie -konferensiekomitees.

- IRS se duisende lede, intekenare en ander ondersteuners.

- Die grootste deel van die IRS-werk is pro Deo, gratis deur vrywillige, entoesiastiese Christene (plaaslik en in die buiteland) gedoen. Die IRS het die voorreg gehad om te kon staatmaak op bekwame skrywers, keurders, raadgewers, beplanners en nog meer.

- Die IRS se konferensies was 'n kragtige middel tot reformasie. Juis omdat die konferensies nie bloot intellektueel-akademiese gebeurtenisse was nie, maar diep religieus-lewensbeskoulike ervarings, was hulle effektief om mense se verstarde, gestolde lewensvisies en ideologieë te verander - vir sommige soms 'n baie traumatiese, maar nogtans heilsame proses.

- Die IRS kon met die vinger op die pols van die tyd die politieke, sosiale, ekonomiese, akademiese en ander implikasies van die evangelie bekendmaak en uitleef en ander aanmoedig om by-dieWoord en byderwets te dink en te doen.

\subsection{Enkele wenke in die lig van die geskiedenis van die IRS}

Gedagtig aan wat met die IRS gebeur het, behoort Christelike aksies onder andere op die volgende te let:

- Hulle moet volgens 'n integrale (nie ambivalente) Christelike lewensvisie gemotiveer en bestuur word (vgl. Klapwijk, 1995:93114).

- Hulle mag nooit as vertoonvenster (met ander woorde vir eie belang) bestaan nie, maar moet na buite beweeg - in diens van God en die medemens. Om dit te kan bereik, moet hulle voortdurend op hoogte bly met die vrae en behoeftes (konteks) van diegene wat hulle wil dien.

- Omdat 'n ideologie verblind, verdwaas en met mag afgedwing word, moet sulke organisasies - al word hulle ook deur 'n Christelike lewensvisie geïnspireer - altyd daarvoor waak dat hulle nie verideologiseerd raak nie. Dit vra openheid om voortdurend in die lig van God se openbaring in die Skrif en in die konkrete werklikheid gekorrigeer (getransformeer) te word. 
- Christelike organisasies/instellings moet, indien enigsins moontlik, selfstandig of onafhanklik wees en nie aan 'n ander verband (soos 'n kerk of 'n universiteit) verbonde wees nie. (Vgl. die Reformatoriese samelewingsbeginsel van soewereiniteit in eie kring.) Hulle "van" (Christelike) moet hulle voortdurend daaraan herinner dat hulle nie aan mense of partye behoort nie, maar aan hulle Koning, Jesus Christus.

- Toegewyde lede, wat die organisasie/instelling ten volle steun en volledig op hoogte is van alle fasette van die bestuur daarvan, is 'n verdere vereiste. Dit kan voorkom dat hulle kritiekloos outoritêre optrede sal aanvaar. Van sy kant behoort die bestuur bereid te wees om op deursigtige wyse aan die lede oor al sy aktiwiteite verantwoording te doen.

- Vanselfsprekend werk Christelike organisasies vandag (die 21ste eeu) in 'n totaal ander geestesklimaat as dié waarin die IRS in 1962 ontstaan en daarna gewerk het. In dié verband kan byvoorbeeld die volgende in gedagte gehou word: 'n nuwe liberaal-sekulêre Suid-Afrikaanse Grondwet; alle godsdienste word nie net vryheid gegun nie, maar ook as prinsipieel gelykwaardig beskou; die postmodernistiese relativisme; 'n vinnig toenemende sekulêre samelewing; 'n nuwe soort piëtisme ("emigrasie na binne") by baie Christene; 'n neo-liberale, globale vryemarkekonomie, wat tot die verkommersialisering van al die ander nie-ekonomiese fasette van die lewe lei; en nuwe vorme van kerkisme of denominasionalisme. Al dié faktore saam roep totaal nuwe vrae op wat ook nuwe antwoorde vanuit 'n Christelike perspektief noodsaaklik maak.

Die nuwe Noordwes-Universiteit (die Potchefstroomkampus ingesluit) word byvoorbeeld tans in 'n "pluralistiese" rigting gedwing. Dit kan bloot 'n voorfase tot sy volledige sekularisering wees, maar dit hoef nie noodwendig te gebeur nie. Voorlopig bestaan die moontlikhede nog om nuwe Christelike groeipunte te vestig, wat met inagneming van die nuwe geestesklimaat, in die toekoms kan gedy.

\subsection{Voorbeelde trek}

Omdat die geskiedenis nie slegs 'n binnewêreldse proses is nie, maar goddelike geheime bevat (vgl. Klapwijk, 1987), verloop dit nie altyd soos ons dit graag sou wens nie. Bó die onsekerheid egter staan God se belofte dat ons inspanning in sy diens nooit tevergeefs is nie (1 Kor. 15:58). Daarom kan ons "standvastig, onwankelbaar, altyd oorvloedig in die werk van die Here" volhard. 
Al het die IRS in 1999 in Suid-Afrika gesterf, herleef dit in 2005 in Korea. Die Kosin Universiteit in Busan stig in 2006 'n IRS "wat in die tradisie van die IRS van Potchefstroom wil voortwerk" en die afgetrede direkteur van die ou IRS word die eredirekteur van hierdie nuwe IRS. Daar kan dus inderdaad iets geleer word uit die geskiedenis van die IRS.

\section{Terugblik}

Indien die hipotese van hierdie ondersoek waarheid bevat, is aangetoon hoe 'n belangrike rol lewensbeskoulike verskille (wat politieke oortuigings insluit) - selfs onder Christene - kan speel. Sodanige verskille kan bydra tot die totstandkoming, maar ook die terminering van Christelike aksies. Dié feit benadruk die noodsaak van 'n grondige besinning by die stigting van Christelike organisasies oor die motiewe daaragter, die konteks waarbinne hulle moet funksioneer, hulle karakter, doel, struktuur, funksies en so meer. Dit is veral belangrik dat sulke organisasies/instellings gedra sal word deur 'n ondersteuningsgemeenskap met 'n gemeenskaplike, integraal-Christelike lewensvisie. Kerke het 'n beperkte taak in die samelewing. Lewensbeskoulik-georiënteerde Christelike organisasies kan egter op talle ander lewensterreine, te midde van 'n groeiende sekulêre klimaat, weer 'n duidelike stem laat hoor.

\section{Naskrif:}

\section{Die spesiale bydrae van Theo van der Merwe}

Vir prof. N. Theo van der Merwe (1932-2004) het die ideale van die PU vir $\mathrm{CHO}$ en die IRS ná aan die hart gelê. Hy was geïnspireer deur die Reformatoriese lewensvisie en het ook geweet wat dit inhou. Daarom het hy ook geglo aan die noodsaaklikheid van die IRS. Sy betrokkenheid by die IRS het bewys dat hy nie net 'n akademikus van statuur was nie, maar ook 'n oog gehad het vir die alledaagse praktiese lewe van Christene.

Van der Merwe se bydrae tot die IRS het veral op die vlak van beleid en bestuur gelê, waaroor veral op die IRS se Raad van Beheer en Dagbestuur besluit is. Hy het vanaf 1978 ononderbroke vir dertien jaar op die IRS-Raad en Dagbestuur gedien, vanaf 1982 tot 1991 as vise-voorsitter en gedurende 1987 as waarnemende voorsitter (vgl. Jaarverslae van 1978:2 en 1982:2). Hy was dus betrokke totdat die IRS in die SRW opgeneem is. 
Dit was egter nie net die jare wat hy sy tyd, kragte en insigte ter beskikking van die IRS gestel het nie, maar ook die wyse waarop hy dit gedoen het. Hy kon baie beslis, maar steeds kalm en beheersd, 'n prinsipiële standpunt inneem. Veral gedurende die polities spanningsvolle jare vanaf 1988 en daarna, het hy hom nie deur ander bestuurslede, wat die IRS in 'n ideologiese rigting wou stuur, laat domineer nie. Sy helder brein, duidelike Bybelsbegronde denke en sin vir geregtigheid het dikwels die deurslag gegee. Sy lojale ondersteuning was deur al die jare 'n besondere bron van bemoediging en inspirasie.

Soos dikwels gebeur, het Theo van der Merwe, behalwe vir sy akademiese werk, nie vir sy bydrae tot die IRS die nodige erkenning ontvang nie. By wyse van hierdie bydrae word dus erkenning gegee aan en dankbaarheid betuig teenoor ons hemelse Vader. Theo van der Merwe se besondere visie, wysheid, skerpsinnigheid, geduld, offervaardigheid en diplomasie was 'n onontbeerlike sleutel in die werk van die IRS. Sy voorbeeld het ook my eie lewe verryk, verbreed en verdiep.

Sy grootste bydrae lê dalk daarin dat hy telkens daarop gewys het dat dit die seën van die Here is wat ons ryk maak - al ons moeitevolle arbeid baat daarsonder niks nie (Spr. 10:22). Die mens se werk kan alleen sinvol wees indien die sin daarvan geleë is in Hom, wat dié Sin van alles is (Rom. 11:36). Nog anders gestel: Theo het iets begryp van wat dit beteken toe Christus gesê het: "Beywer julle allereers vir die koninkryk van God en vir die wil van God ..." (Matt. 6:33). Daarom eer ons sy nagedagtenis.

\section{Geraadpleegde bronne}

BUIJS, G. et al. 2003. Wat je zegt, ben je zelf; identiteit en Christelijke organisaties. Zoetermeer: Boekencentrum.

BUYS, P.J. 1987. Calvinism does not teach apartheid. Potchefstroom: IRS. (Studiestuk, nr. 233.)

COETZEE, J.H. 1987. Christelik-nasionale onderwys geweeg in die lig van die ekumeniese roeping van die PU vir CHO. Potchefstroom: IRS. (Studiestuk, nr. 235.)

DUVENAGE, S.C.W. 1983. Die Instituut vir Reformatoriese Studie: 'n evaluering. (In Van der Walt, B.J. IRS: 1962-1982. Potchefstroom: IRS. p. 8-15.)

GOUDZWAARD, B. 1981. Genoodzaakt goed te wezen: christelijke hoop in een bezeten wêreld. Kampen: Kok.

GOUDZWAARD, B. 1984. Idols of our time. Sioux Center: Dordt College. 
INSTITUUT VIR DIE BEVORDERING VAN DIE CALVINISME. 1974-1980. Jaarverslae aan die Raad van Beheer van die IBC. Potchefstroom: PU vir $\mathrm{CHO}$.

INSTITUUT VIR REFORMATORIESE STUDIE. 1981-1999. Jaarverslae aan die Raad van Beheer van die IRS en die Senaatskomitee vir Reformatoriese Wetenskapsbeoefening. Potchefstroom: $\mathrm{PU}$ vir $\mathrm{CHO}$.

KLAPWIJK, J., red. 1987. De eerste en tweede geschiedenis: nagelaten geschriften van Meijer C. Smit. Amsterdam: Buijten \& Schipperheijn.

KLAPWIJK, J. 1995. Christelijke organisaties in verlegenheid. (In Klapwijk, J. Transformationele filosofie: cultuurpolitieke ideeën en de kracht van een inspiratie. Kampen: Kok Agora. p. 91-123.)

KLEP, P., HOETINK, C. \& EMONS, T., reds. 2005. Persoonlijk verleden: over geskiedenis, individu en identiteit. Amsterdam: Aksant.

OVERDUIN, J. 1978. Faith and victory of Dachau. St. Catherines: Paideia.

SPYKMAN, G.J. 1985. Spectacles: Biblical perspectives on Christian scholarship. Potchefstroom: $\mathrm{PU}$ vir $\mathrm{CHO}$.

TURAKI, Y. 1992. An African response to the question of apartheid. Potchefstroom: IRS. (Studiestuk, nr. 294.)

VAN DER MERWE, N.T. 2000. Die IRS - 'n kragsentrale van Bybelgetroue denke. Koers, 65(1):163-166.

VAN DER WALT, B.J. 1976. Is die Christelik-nasionale beginsel Calvinisties? Fokus, 4(4):397-410.

VAN DER WALT, B.J., red. 1980a. Die inslag van die Calvinisme in Suid-Afrika: 'n bibliografie van Suid-Afrikaanse tydskrifartikels (4 dele). Potchefstroom: IBC.

VAN DER WALT, B.J. 1980b. Van Noyon na Genève: reisindrukke van 'n Calvynpelgrim. Noordbrug: Calvyn-Jubileumboekefonds.

VAN DER WALT, B.J. 1983a. Die Instituut vir Reformatoriese Studie: twintig jaar van diens (1962-1982). (In Van der Walt, B.J., Bingle, H.J.J., Duvenage, S.C.W. \& Van der Walt, T. IRS: 1962-1982. Potchefstroom: IRS. p. 8-15.)

VAN DER WALT, B.J. 1983b. Visie, werklikheid, visioen: flitsindrukke van die IRS-konferensie van 4 en 5 November 1983 oor "Die betekenis van die Reformatoriese lewensvisie vir Afrika". Potchefstroom: Instituut vir Reformatoriese Studie.

VAN DER WALT, B.J., red. 1984. Ideologiese stryd in Suid-Afrika - vlug vir die afgode! Potchefstroom: IRS.

VAN DER WALT, B.J. 1989a. Vooraf/Preface. (In Van der Walt, B.J. et al. Visie en Missie/Vision and Mission: IRS 25 jaar/years (1962-1987). Potchefstroom: IRS. p. 1-12.)

VAN DER WALT, B.J. 1989b. Potchefstroom, Afrika roep jou! (In Van der Walt, B.J. et al. Visie en Missie/Vision and Mission: IRS 25 jaar/years (19621987.) Potchefstroom: IRS. p. 13-70.)

VAN DER WALT, B.J. 1989c. Die roeping van owerheid en onderdaan in SuidAfrika, "anno Domini": 1989. Potchefstroom: IRS. (Studiestuk, nr. 257.)

VAN DER WALT, B.J. 1995a. Die hand in eie boesem: 'n besinning oor Afrikaneridentiteit. Potchefstroom: IRS.

VAN DER WALT, B.J. 1995b. Bybelse perspektiewe op die samelewing. Potchefstroom: IRS. (Studiestuk, nr. 331.)

VAN DER WALT, B.J. 1997. 'n Skuldbelydenis oor apartheid. Potchefstroom: IRS. (Studiestuk, nr. 355.) 
VAN DER WALT, B.J. 1998. Flitsgedagtes oor die identiteit van die PU vir CHO (1869-1994). Supplement 1 tot Koers. Koers, 63:363-402.

VAN DER WALT, B.J. 2000. Die sinvraag in ons verhouding tot die natuur en in die geskiedenis van die IRS (1962-1999). Koers, 65(1):123-162.

VAN DER WALT, B.J. 2003. Identiteit en relevansie: die dringende noodsaak van Christelike organisasies en instellings in 'n toenemende sekulêre Suid-Afrika. Tydskrif vir Christelike Wetenskap, 39(3 \& 4):131-148.

VAN DER WALT, B.J. 2004a. Sekularisme, die gees van ons tyd (1): 'n bedreiging. Tydskrif vir Christelike Wetenskap, 40 (1\& 2):85-98.

VAN DER WALT, B.J. 2004b. Sekularisme, die gees van ons tyd (2): 'n tipering. Tydskrif vir Christelike Wetenskap, 40(3):93-114.

VAN DER WALT, B.J. 2005a. Sekularisme, die gees van ons tyd (3): 'n antwoord. Tydskrif vir Christelike Wetenskap, 41 (1 \& 2):43-74.

VAN DER WALT, B.J. 2005b. Hoe 'n stem van Potchefstroom stilgemaak is: 'n persoonlike blik op die geskiedenis van die IRS (1962-1999). Ongepubliseerde manuskrip. (Beskikbaar in die Argief van die Potchefstroomkampus van die Noordwes-Universiteit).

VAN DER WALT, B.J. 2005c. Dertig jaar (1975-2005) internasionale aksie vir Christelike Hoër Onderwys: enkele persoonlike indrukke. Koers, 70(3):555-574.

VAN DER WALT, B.J. \& VAN DER WALT, T. 1996. Die Waarheids- en Versoeningskommissie. Potchefstroom: IRS. (Studiestuk, nr. 342.)

VAN DER WALT, B.J. \& VENTER, J.J. 1998. Godsdiens en samelewing/ Religion and society: a review of the Truth and Reconcilliation Commission Hearings, East London, 17-19 November 1997. Potchefstroom: IRS. (Studiestuk, nr. 361.)

VAN DER WALT, T. 1983. Die diens van die Instituut vir Reformatoriese Studie aan die gemeenskap. (In Van der Walt, B.J. IRS: 1962-1982. Potchefstroom: IRS. p. 25-29.)

VAN EEDEN, E.S., red. 2005. "In U lig": die PU vir CHO van selfstandigwording tot samesmelting, 1951-2004. Potchefstroom: Noordwes-Universiteit, Potchefstroomkampus.

VEENHOF, J. 1994. The relationship between nature and grace according to $\mathrm{H}$. Bavinck. Potchefstroom: IRS. (Studiestuk, nr. 322.)

VENTER, J.J. 1984. Die behoefte en dringende noodsaaklikheid van Christelike universitêre opleiding vir bruin en swart Suider-Afrikaners. Potchefstroom: IRS. (Studiestuk nr. 195.)

WELLS, R.A. 1989. History through the eyes of faith: Western civilization and the kingdom of God. San Francisco: Harper \& Row.

WOLTERS, A.M. 1992. Die skepping herwin: Bybelse grondslae vir 'n Reformatoriese lewensbeskouing. Potchefstroom: IRS. 


\section{Kernbegrippe:}

Christelik-nasionale lewensvisie

Christelike organisasies Instituut vir Reformatoriese Studie (IRS)

Potchefstroomse Universiteit vir Christelike Hoër Onderwys Reformatoriese lewensvisie

\section{Key concepts:}

Christian-national worldview Christian organisations Institute for Reformational Studies (IRS) Potchefstroom University for Christian Higher Education Reformational worldview 